POLITYKA ENERGETYCZNA - ENERGY POLICY JOURNAL

$2019 \star$ Volume $22 \downarrow$ Issue $1 \nrightarrow 39-58$

DOI: $10.33223 / \mathrm{epj} / 105366$

Maciej MIECZNIK ${ }^{1}$, Robert SKRZYPCZAK ${ }^{2}$

\title{
Initial assessment of the possibility of using ATES technology in Poland by low-temperature heat and cold consumers
}

ABSTRACT: The aim of the article is a preliminary assessment of the possibility of using ATES (Aquifer Thermal Energy Storage) technology for the seasonal storage of heat and cold in shallow aquifers in Poland. The ATES technology is designed to provide low-temperature heat and cold to big-area consumers. A study by researchers from the Delft University of Technology in the Netherlands indicates very favorable hydrogeological and climate conditions in most of Poland for its successful development. To confirm this, the authors used public hydrogeological data, including information obtained from 1324 boreholes of the groundwater observation and research network and 172 information sheets of groundwater bodies (GWBs). Using requirements for ATES systems, well-described in the world literature, the selection of boreholes was carried out in the GIS environment, which allowed aquifers that meet the required criteria to be captured. The preliminary assessment indicates the possibility of the successful implementation of ATES technology in Poland, in particular in the northern and western parts of the country, including the cities of: Gdańsk, Warsaw, Wrocław, Bydgoszcz, Słupsk, and Stargard.

KEYWORDS: Aquifer Thermal Energy Storage, ATES, heat storage in aquifers, underground storage of heat and cold

${ }^{1}$ The Mineral and Energy Economy Research Institute of the Polish Academy of Sciences, Kraków, ORCID: 0000-0002-6655-9814; e-mail: miecznik@min-pan.krakow.pl

2 The Mineral and Energy Economy Research Institute of the Polish Academy of Sciences, Kraków, ORCID: 0000-0003-2141-028X; e-mail: robskrzy@min-pan.krakow.pl 


\section{Introduction}

In 2010, in the European Union countries, the direct use of heat (in all sectors of the economy) accounted for about $47 \%$ of total final energy consumption (ETP RHC 2013), while in 2015 the residential sector alone used $25.4 \%$ of final energy (in Poland $30.3 \%$ ) - mostly for heating purposes (EC 2017). In particular, energy consumption for heating and hot tap water in the residential sector of the European Union countries in 2016 amounted to more than $79 \%$ of total final energy demand (heating and hot tap water $-64.6 \%$ and $14.5 \%$, respectively; Eurostat 2018). In the case of Poland, the final energy consumption for heating needs is even higher and amounted to $66.4 \%$ for heating and $15.8 \%$ for hot tap water (in total $82.2 \%$ ). Despite the fact that the current energy consumption for cooling purposes is relatively small (the EU-28 average is $0.3 \%$ of final energy consumption in the housing sector), according to the report of the Intergovernmental Panel on Climate Change (IPCC), up to a 33-fold increase to 2100 on a global scale is expected, with an estimated $25 \%$ due to climate change (IPCC 2014). It should be mentioned that although the share of renewable energy sources (RES) in final energy consumption for heating needs in Poland is slowly growing - from $10.2 \%$ in 2005 to $14.7 \%$ in 2016 , it is much lower than in such countries like Sweden (68.6\%), Finland (53.7\%), and Latvia (51.9\%). It should be mentioned that the dominant form of renewable energy used for heating purposes is solid biomass. The above-mentioned data clearly indicates that the increase in the share of non-biomass energy sources in the heating sector (residential, municipal, and all types of service buildings) can contribute to a clear improvement in air quality by reducing emissions of carbon dioxide and sulfur dioxide, nitrogen oxides, and suspended particulate matter (PM2.5 and PM10).

Aquifer Thermal Energy Storage (ATES) is a technology that enables thermal energy in shallow aquifers to be stored and recovered. This is one of the types of underground thermal energy storage, collectively referred to as UTES (Underground Thermal Energy Storage) also including heat storage using borehole heat exchangers (BTES - Borehole Thermal Energy Storage), underground tanks (TTES - Tank Thermal Energy Storage), gravel-water pits (PTES - Pit Thermal Energy Storage), or rock caverns (CTES) - Cavern Thermal Energy Storage). ATES is designed to supply heat and cold to distributed consumers, located outside municipal heating networks. This technology began to enter the commercial phase in the 1990s and since then there has been a rapid increase in the number of new installations, especially in the Netherlands and the Scandinavian countries (Fleuchaus et al. 2018).

The resented paper is focused on heat and cold storage in shallow aquifers. The basic principles and conditions for the operation of ATES systems and the development and the current status of the technology in the world are discussed later in the article. The main goal is to indicate the possibilities of using this technology in Poland, taking favorable climatic and hydrogeological conditions that are advantageous both regionally and locally into account. Using publicly available hydrogeological data, including aquifer data contained in 1324 wells of the groundwater observation and research network and 172 groundwater bodies (GWBs) data sheets (Herbich 
et al. 2005), the authors made a preliminary selection of potential areas meeting the criteria set for ATES systems.

\section{The theoretical basis of operation of ATES systems}

The system of low-temperature heat and cold storage in the aquifer consists of two wells (called a doublet) with one cold storage well and heat storage well. In the summer season, water with a temperature of approx. $5-10^{\circ} \mathrm{C}$, extracted from the cold storage well, is directed to the heat exchanger in which it receives heat from an air-conditioned building. After passing through the exchanger, the water is preheated to a temperature of approx. $15-18^{\circ} \mathrm{C}$ and is injected into the hot storage well. The circulation is reversed in the winter season. Groundwater with elevated temperature is pumped from the hot well and directed to the evaporator of a heat pump that enables the return water from the building to be heated to a temperature of approx. $40-50^{\circ} \mathrm{C}$, while water supplied from the aquifer is cooled to a temperature of approx. $5-10^{\circ} \mathrm{C}$, and then injected into the cold storage well (Nordel et al. 2015; Bloemendal et al. 2018). The diagram of the operation of the ATES system under the cyclic flow regime is shown in Figure 1.
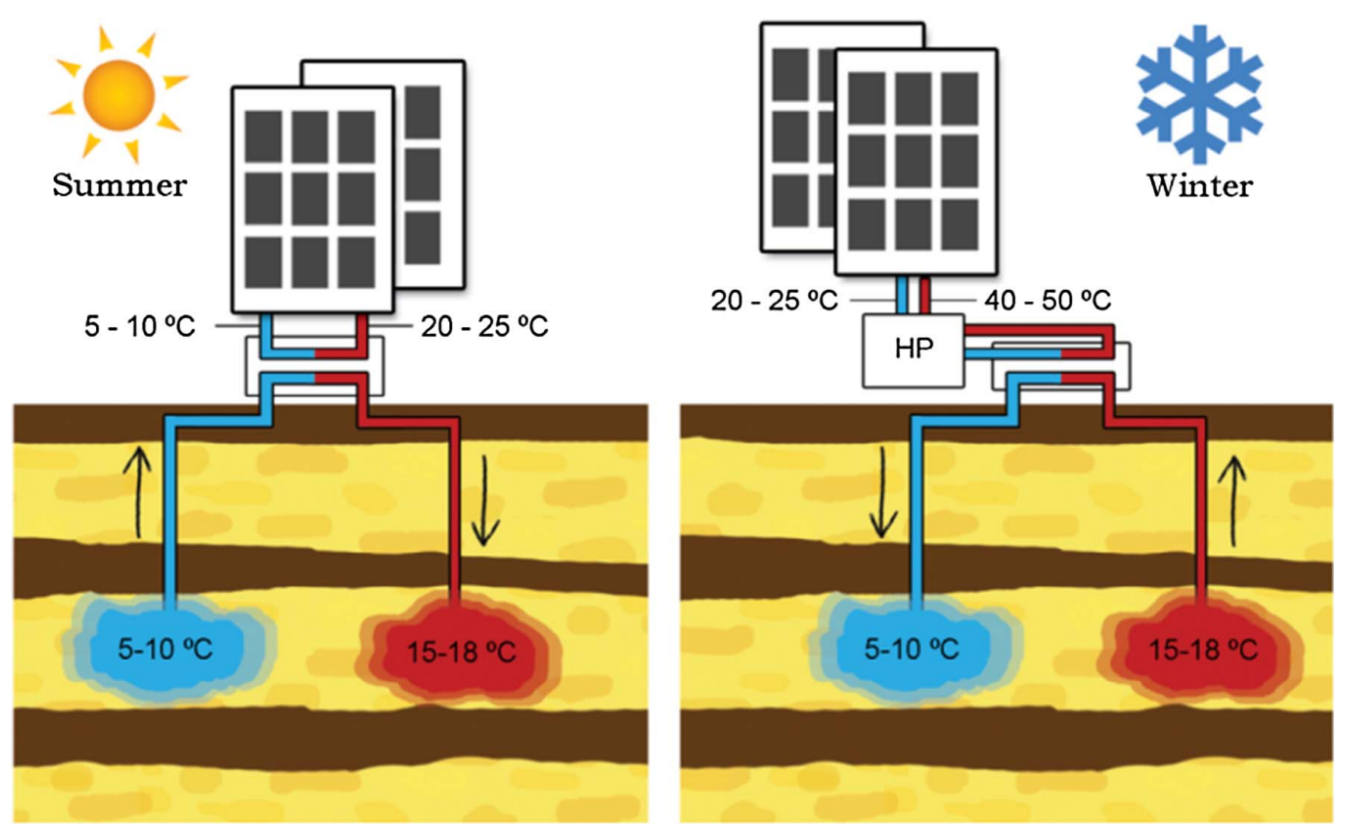

Fig. 1. Diagram illustrating the operation of the ATES under cyclic flow regime (Bloemendal et al. 2018)

Rys. 1. Schemat ilustrujący pracę systemu ATES w trybie cyklicznym 
The ATES system works most often under a cyclic flow regime: summer season - winter season. Each well serves both as a production and injection well. If the temperature of water in a cold storage well in the summer season is $6^{\circ} \mathrm{C}$ or lower, it can be used directly for cooling, i.e. bypassing the heat pump. The Seasonal Performance Factor $\left(\mathrm{SPF}^{1}\right)$ of the heat pump, taking the above temperatures of the lower heat source into account, can reach 5.5-6 (using ground heat exchangers without heat storage SPF is 3.8-4.3), while in the cooling mode SEER (Seasonal Energy Efficiency Ratio ${ }^{2}$ ) may exceed $60 \mathrm{Btu} / \mathrm{Wh}$, which is from 4 to 6 times more efficient than the conventional systems (Underground Energy LLC 2019). It allows for better efficiency than in the case of classic open-loop heat pump systems, higher energy savings, and a greater value of the avoided emissions.

In general, ATES systems operating under cyclic flow regime require the occurrence of an aquifer capable of collecting and releasing water (water-bearing sands and gravels with a thickness $>10 \mathrm{~m}$, usually $20-50 \mathrm{~m}$ ), with a high hydraulic conductivity (above $3 \cdot 10^{-5} \mathrm{~m} / \mathrm{s}$ ), and at the same time a small hydraulic gradient and low natural filtration velocity $(<25 \mathrm{~m} / \mathrm{year}$, which allows for minimizing the advective heat loss), limited from the bottom and top by impermeable layers (e.g. clay) to protect against mixing warm and cold water, e.g. rainwater (Lee 2013; Nordell et al. 2015; Malina and Bujak 2017). Geochemical gradients should also be avoided because mixing of water of different chemical compositions can cause the colmatation of well filters, contribute to a lower efficiency and performance of wells, and increased operating costs of the system.

The ATES systems operating under a continuous flow regime are much less common (Nielsen 2003). Under a continuous flow regime, each well has a strictly defined role - it is either a production or injection well. Such ATES systems are an alternative solution for aquifers with high filtration velocity ( $>50 \mathrm{~m} /$ year). In this mode, ATES systems operate at a lower temperature difference between the natural temperature of the aquifer and the zones around the production and injection wells, which results in lower energy efficiency.

Typically, thermal energy from the ATES system is supplied to buildings that require cooling in the summer season and low-temperature heating during winter (i.e. underfloor heating or air heating). Thus, energy consumers may be: residential buildings, office buildings, hospitals, computer centers that require continuous cooling, museums, warehouses, greenhouses, railway stations, and airport terminals. They do not have to be connected to the heating network, because ATES systems can be located near or directly under the facility.

\footnotetext{
1 The SPF is a measure of the operating performance of an electric heat pump heating system over a year. This is the ratio of the heat delivered to the total electrical energy supplied to the heat pump over the year: SPF $=$ Total heat output over a year $[\mathrm{kWh}] /$ Total input electricity over a year $[\mathrm{kWh}]$.

2 The SEER rating is a measure of the seasonal efficiency of air conditioners. It is the cooling output during a typical cooling season (expressed in Btu) divided by the total electric energy input during the same period $(\mathrm{W} \cdot \mathrm{h})$.
} 


\section{The use of ATES technology in the world}

The global development of ATES technology from its historical origins to the present state is comprehensively presented by Fleuchus et al. (2018). The first installations related to water storage in shallow aquifers were made in China in the mid-1960s. Although the main intention of these operations was to slow down the process of land subsidence caused by the excessive extraction of groundwater by the textile industry, it was quickly noticed that the injected water maintains an almost constant temperature for a long time. In this way, the significant potential associated with the use of shallow aquifers for long-term cold storage for industrial purposes was also noticed (Fleuchaus et al. 2018). Despite the initial rapid development of new ATES systems in China, their efficiency was unsatisfactory; moreover, the lack of experience in designing and the ongoing maintenance of this type of installation contributed to the high failure rate. This, in turn, led to numerous technical problems including the colmatation of wells and heat exchangers, and, as a consequence, the development of the technology was abandoned in the 1990s. (Nordell et al. 2015)

The initial development of heat storage technology in shallow aquifers in China attracted interest from the scientific community, resulting in the first theoretical and experimental works in the 1970s and the first half of the 1980s. (Kazmann 1971; Meyer and Todd 1973; Werner and Kley 1977; Schaetzle et al. 1980; Sauty et al. 1982a, 1982b). In contrast to China, where ATES installations were used to cool industrial facilities, the initial development of ATES technology in Europe was associated with the storage of water at a temperature above $40^{\circ} \mathrm{C}$ (High-Temperature ATES, HT-ATES), which led to numerous problems related to the change of the chemical composition of water, colmatation and corrosion of wells and heat exchangers, movements of the water thermal front, or lack of balance between heat and cold demand (Fleuchaus et al. 2018). Starting from the second half of the 1990s, the vast majority of ATES systems is based on low -temperature heat storage, i.e. below $40^{\circ} \mathrm{C}$, and often below $20^{\circ} \mathrm{C}$ (Fleuchaus et al. 2018 ; Nordell et al. 2015). Currently, it is estimated that there are over 2800 ATES systems in the world, of which nearly $90 \%$ are in the Netherlands alone (around 2.500 installations), while another $10 \%$ in Sweden (220), Denmark (55) and Belgium (30), and more than 99\% employ low-temperature technology (Fleuchaus et al. 2018). Referring to the data from the Dutch Central Bureau of Statistics, Sommer (2015) reports, in turn, that the number of ATES systems in 2013 already exceeded 3000. Such a strong development of ATES technology in the Netherlands is caused by favorable climatic and hydrogeological conditions in almost the entire territory of the country, common low-energy construction among new investments and the activity of central and local authorities, which have begun to support the development of technologies through transparent and coherent procedures for obtaining permits (Bloemendal et al. 2015; Zeiler et al. 2016; Fleuchaus et al. 2018). In addition to the mentioned countries, new ATES systems are also being developed in the United Kingdom and Germany; their revival is observed in China (Fleuchaus et al. 2018). 
It is estimated that around $70 \%$ of all ATES systems in the Netherlands provide heat and cold for public buildings and commercial buildings (offices, shopping centers, large-scale retail stores, hospitals, and hotels), while the remaining $30 \%$ is supplied to residential buildings, agriculture, and the industry (Nordell et al. 2015). The largest ATES systems in the world provide heat and cold to, among others: the campus of the Technical University of Eindhoven (cooling capacity of $20 \mathrm{MW}$ ), Overhoeks housing estate in Amsterdam (20 MW of heating capacity, $13 \mathrm{MW}$ of cooling capacity), and Stockholm-Arlanda (8-10 MW) and Oslo-Gardermoen airports (8-9 MW) (Miecznik 2016; Honest Buildings 2019). In the case of large ATES systems (capacities in MW), the simple payback period is from 2 to 8 years (Miecznik 2016; Fleuchaus et al. 2018). An example of the successful implementation of the ATES system on a smaller scale is the supply of thermal energy for the KLINA hospital in Brasschaat near Antwerp. Thanks to the ATES system, the primary energy consumption in the hospital was reduced by $71 \%$ compared to the reference state, i.e. using a gas boiler and compressor chillers. The simple payback period for investment outlays, excluding subsidies, was 8.4 years (Vanhoudt et al. 2011). For economic reasons, it is assumed that the investment is profitable when the demand for cooling or heating is at least $200 \mathrm{~kW}$, assuming that both forms of heat will be covered primarily using aquifer thermal energy storage (Nordell et al. 2015).

\section{Possibilities of using ATES technology in Poland}

The question of the use of aquifer thermal energy storage (ATES) in Poland has begun to attract researchers' attention in recent years. In addition to review articles on various technologies of underground heat storage (Miecznik 2016; Kwestarz 2016; Malina and Bujak 2017), preliminary studies, focused on assessing the ability of selected hydrogeological structures in Poland to meet the requirements of ATES systems, were undertaken. The studies focused on the young glacial areas of the Kashubian Lake District (Lemoine 2016), Żarnowiec Plateau (Lemoine 2018), Central Poland - Quaternary and Upper Cretaceous aquifers of the Piotrków area (Bujakowski et al. 2016), and the city of Sochaczew (Skrzypczak et al. 2017), where Quaternary aquifers, and potentially also Oligocene ones, were indicated as prospective water-bearing formations, are especially worth noting.

The analysis of hydrogeological and climatic conditions performed by researchers from the Delft University of Technology (Bloemendahl et al. 2015), taking the demand for both heat and cold in our climate zone into account, suggests that most of Poland has some of the best conditions in the world for the development of ATES systems. The aggregate assessment, including both factors, for Poland ranged from 7.1 to 9.0 on a scale of 1-10 (Fig. 2). The analysis covered the entire world, which makes its spatial resolution low. Despite the growing interest in low-temperature geothermal energy (geothermal heat pumps) in Poland, ATES technology has not received sufficient attention so far. Until now, there are no ATES systems in Poland, which 
is probably partly due to the technology used to develop high-temperature heating networks in Poland. With the development of low-energy building, the ATES technology would undoubtedly have a chance to emerge in Poland. The lack of studies on the evaluation of the applicability of ATES systems fundamentally limits the possibilities of the development of this technology in Poland.

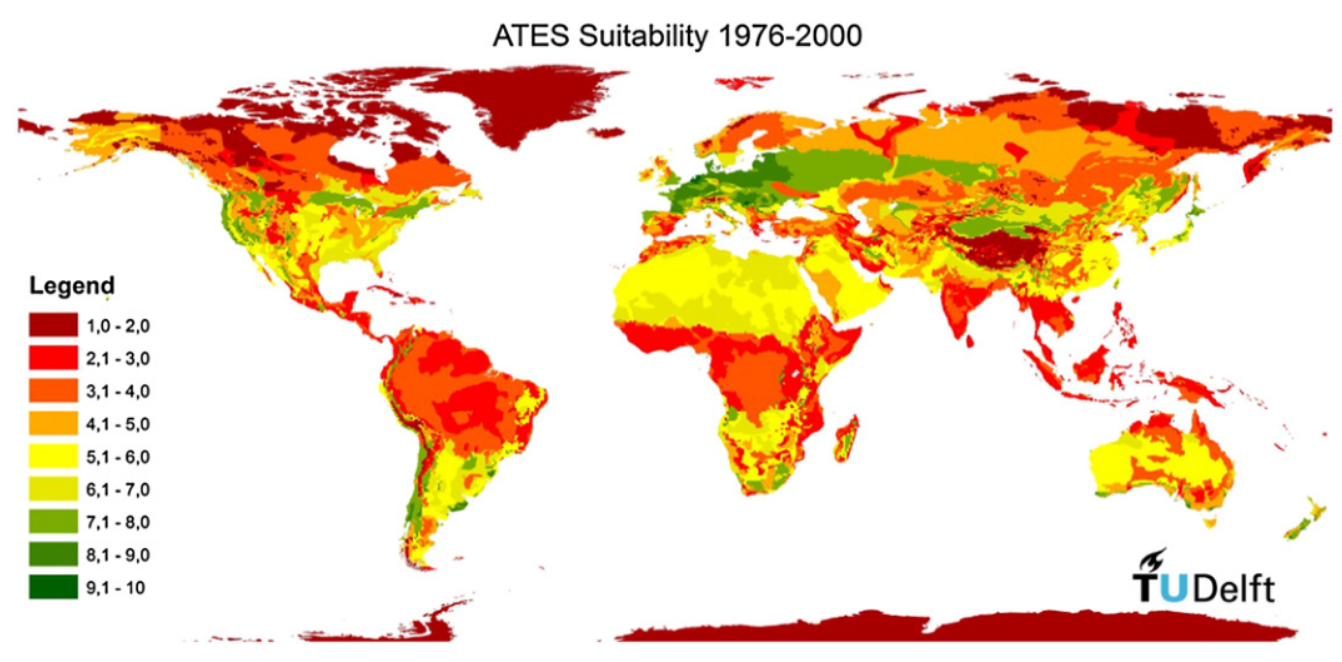

Fig. 2. ATES suitability map based on hydrogeological data and climate observations in the years 1976-2000 (Bloemendal et al. 2015)

Rys. 2. Mapa świata przydatności obszarów do zastosowania technologii ATES na podstawie danych hydrogeologicznych i obserwacji klimatycznych z lat 1976-2000

The impulse for the development of seasonal heat storage in shallow aquifers in Poland requires a comprehensive and widely available study that would combine rich hydrogeological information with technical knowledge about the principles of designing, construction, and trouble-free operation of ATES systems. Such a study requires a team of scientists from the fields of hydrogeology, cartography (GIS), energy, and HVAC designers. In order to meet this challenge, the authors attempted to pre-select the potential areas for ATES systems in Poland, which could be developed after a more detailed hydrogeological analysis. For this purpose, the publicly available hydrogeological data from the Polish Hydrogeological Survey was used:

\ydrogeological characteristics of 172 groundwater bodies (GWBs) (PGI-NRI 2019),

$\checkmark$ aquifer data contained in 1324 wells of the groundwater observation and research network included in the report of the Chief Inspectorate of Environmental Protection (CIEP) on the condition of groundwater bodies in river basins (PGI-NRI 2017). 


\subsection{Baseline data}

The baseline data was a review of the aquifer parameters based on 1324 wells of the groundwater observation and research network. This network is maintained by the Polish Geological Institute - National Research Institute, while its purpose is to document the dynamics and chemistry of groundwater in Poland.

Based on appendix 1 to the report of the Chief Inspectorate of Environmental Protection (CIEP) on the condition of groundwater bodies in river basins (PGI-NRI 2017), the following data was obtained:

$\checkmark$ location of wells,

$\downarrow$ type of porosity of reservoir rocks,

$\checkmark$ stratigraphy and lithology of reservoir rocks,

$\checkmark$ type of the water table in the aquifer,

$\checkmark$ depth to the top of the aquifer,

$\checkmark$ the depth range of the well screens,

$\checkmark$ the depth range of the accessed aquifer,

$\checkmark$ depth of the static water level.

Unfortunately, some key parameters necessary to fully assess the suitability of the aquifer for ATES systems are missing, i.e. the capacity (flow rate) of the wells, the hydraulic conductivity of the aquifer, and the chemical composition of the water. This data can be obtained at the next stage of the verification of wells, using data of the Central Hydrogeological Data Bank (CHDB 2019). Information on the hydraulic conductivity of the aquifer and the chemical type of groundwater can be obtained from groundwater bodies data sheets corresponding to the analyzed wells, which at this stage allows the thesis about the suitability of a given aquifer for ATES systems to be strengthened or rejected. However, such a detailed hydrogeological analysis was not the purpose of this work.

At this stage of the analysis, the authors made maps presenting important reservoir parameters from the point of view of the underground heat storage. Analyzing the map in Fig. 3, it can be seen that over $80 \%$ and $91 \%$ of all wells are located in aquifers whose top is located at a depth not exceeding $50 \mathrm{~m}$ and $100 \mathrm{~m}$ below ground level, respectively. Over $74 \%$ of wells can be found in porous reservoirs, and in a broader perspective - nearly $90 \%$ in porous or porous-fractured media (Fig. 4). About $59 \%$ of the analyzed wells are located in aquifers with a confined water table, while almost $41 \%$ - with a free water table (Fig. 5). 


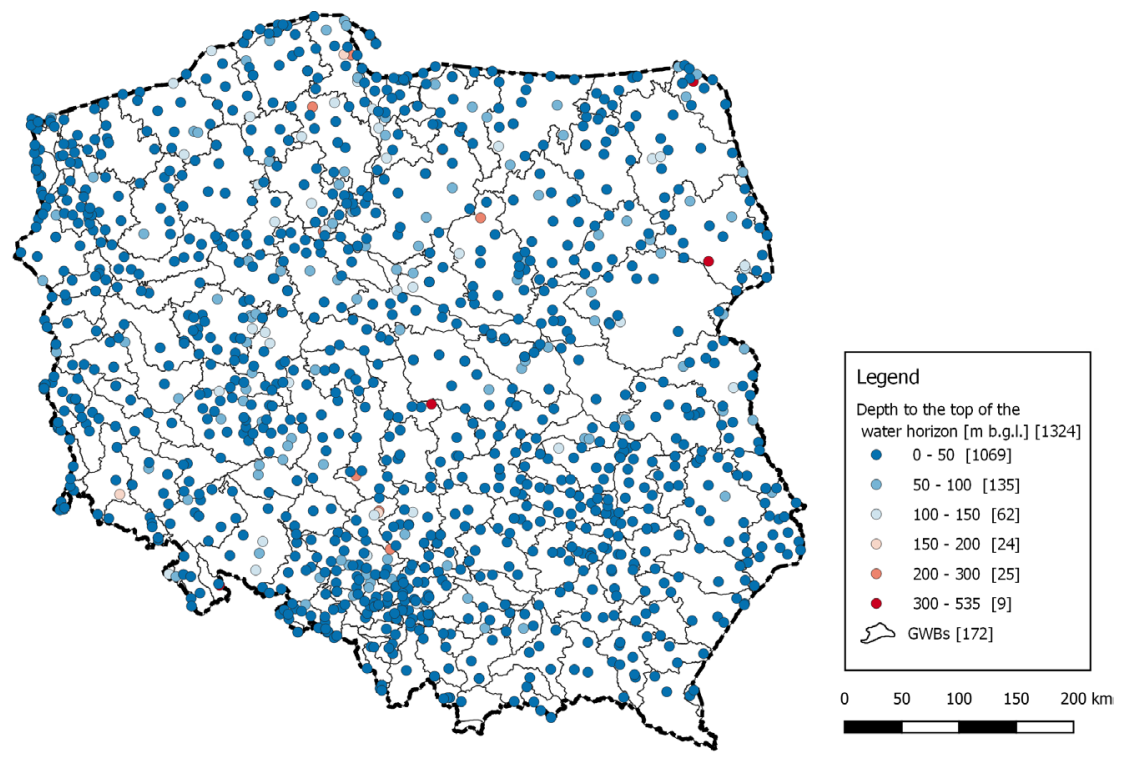

Fig. 3. The distribution of wells of the groundwater observation and research network along with the information on the depth to the top of the aquifer

Rys. 3. Mapa rozmieszczenia otworów sieci obserwacyjno-badawczej wód podziemnych wraz z informacją o głębokości zalegania stropu ujętej warstwy wodonośnej

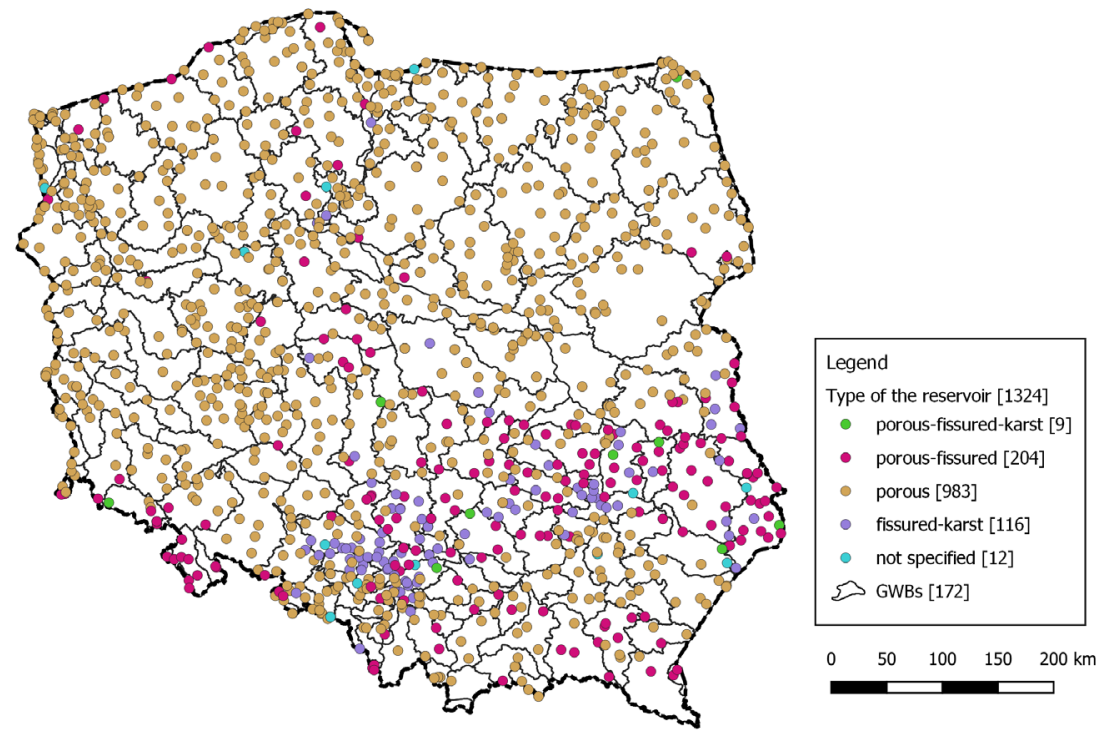

Fig. 4. The distribution of wells of the groundwater observation and research network along with the data on the type of reservoir porosity

Rys. 4. Mapa rozmieszczenia otworów sieci obserwacyjno-badawczej wód podziemnych wraz z informacją o typie skał budujących ujętą warstwę wodonośną 


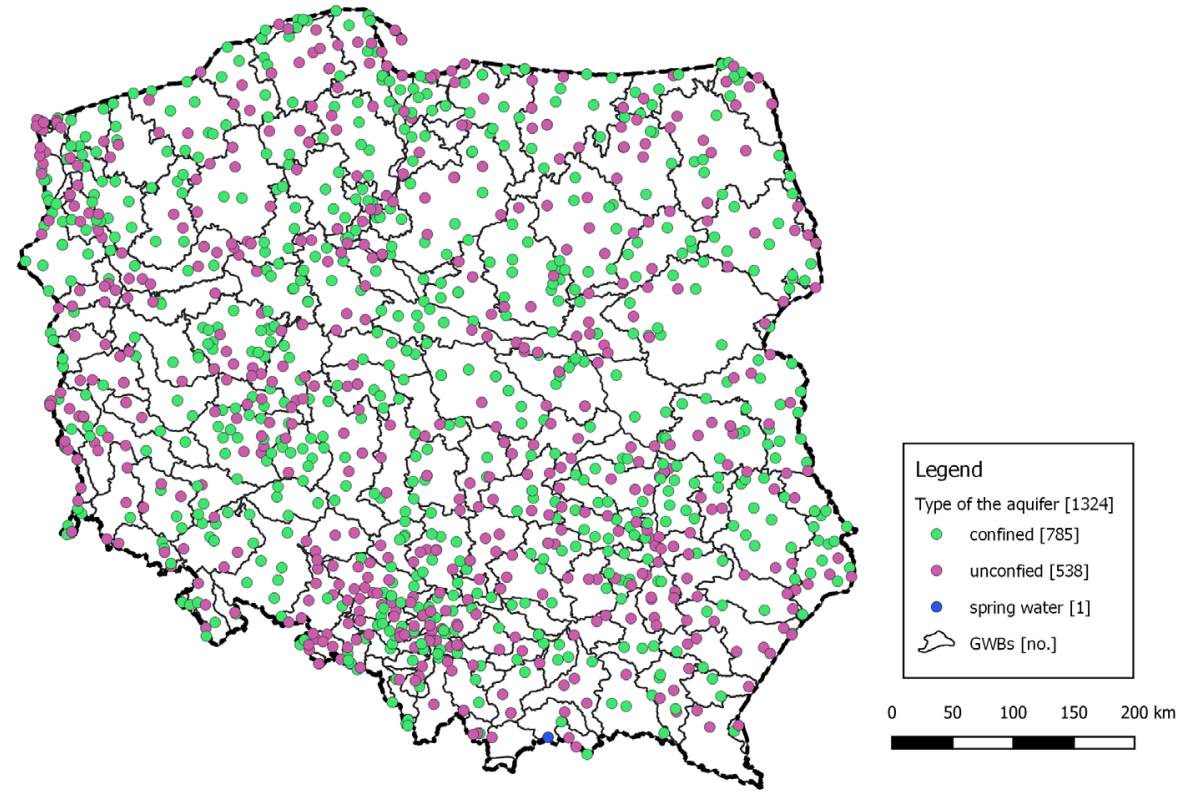

Fig. 5. The distribution of wells of the groundwater observation and research network along with the data on the type of water table of the aquifer

Rys. 5. Mapa rozmieszczenia otworów sieci obserwacyjno-badawczej wód podziemnych wraz z informacją o typie zwierciadła ujętej warstwy wodonośnej

\subsection{The first stage of selection}

In the first stage of selection the following criteria for wells were used (Lee 2013; Nordell et al. 2015; Malina and Bujak 2017):

$\checkmark$ the depth of the top of the aquifer should be min. $10 \mathrm{~m}$, but shall not exceed $200 \mathrm{~m}$ below the ground level,

$\downarrow$ porous or porous-fractured reservoir,

$\downarrow$ confined water table of the aquifer,

$\downarrow$ the thickness of the aquifer $\geq 10 \mathrm{~m}$.

The selection resulted in 213 wells meeting the above criteria (16\% from the initial pool), with the majority of wells located in western and north-western Poland (Fig. 6-8). Nearly 77\% of the wells are located in aquifers whose top is located at a depth of up to $100 \mathrm{~m}$ below ground level. (Fig. 6). At the same time, over $45 \%$ of wells (97 out of 213 ) are located in the Quaternary aquifers, followed by the Miocene aquifers (30 out of 213 , Fig. 7 ). In about $84 \%$ of the cases, the static water table of the aquifer stabilizes at a depth not exceeding $20 \mathrm{~m}$ below the ground level, which suggests low pumping costs in the case of investment (Fig. 8). 


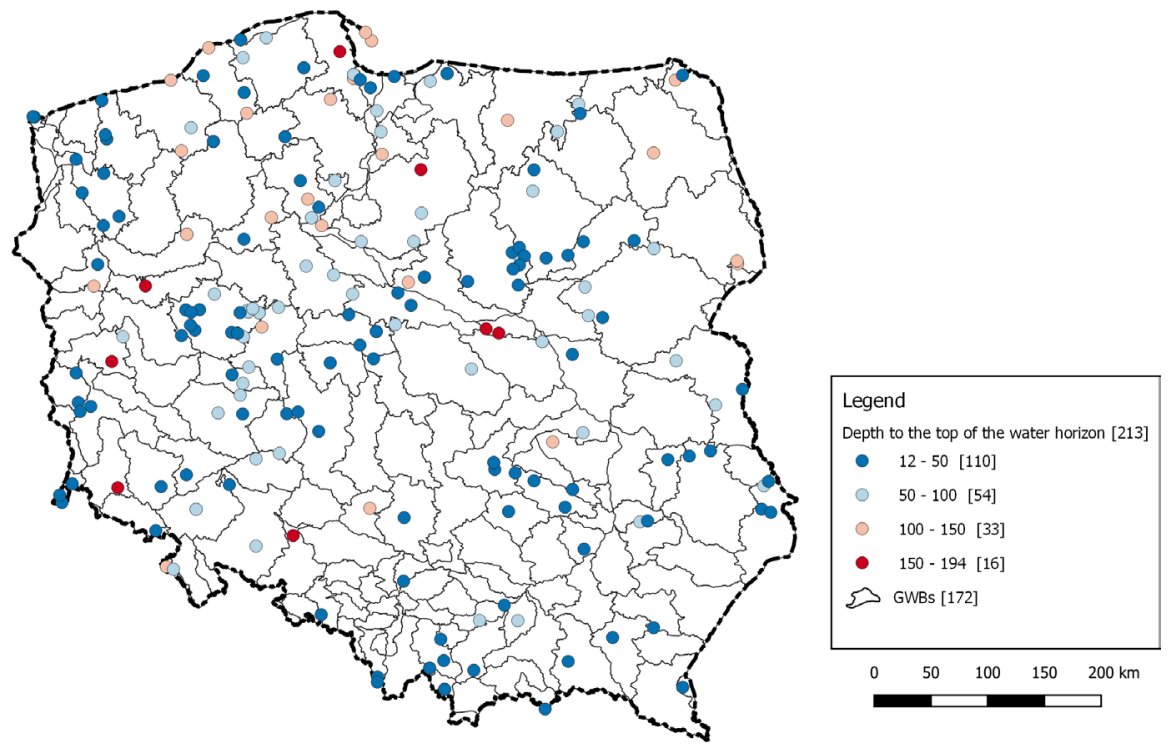

Fig. 6. The distribution of wells of the groundwater observation and research network along with the information on the depth to the top of the aquifer after the first selection stage

Rys. 6. Mapa rozmieszczenia otworów sieci obserwacyjno-badawczej wód podziemnych wraz z informacją o głębokości zalegania stropu ujętej warstwy wodonośnej po wykonaniu pierwszego etapu selekcji
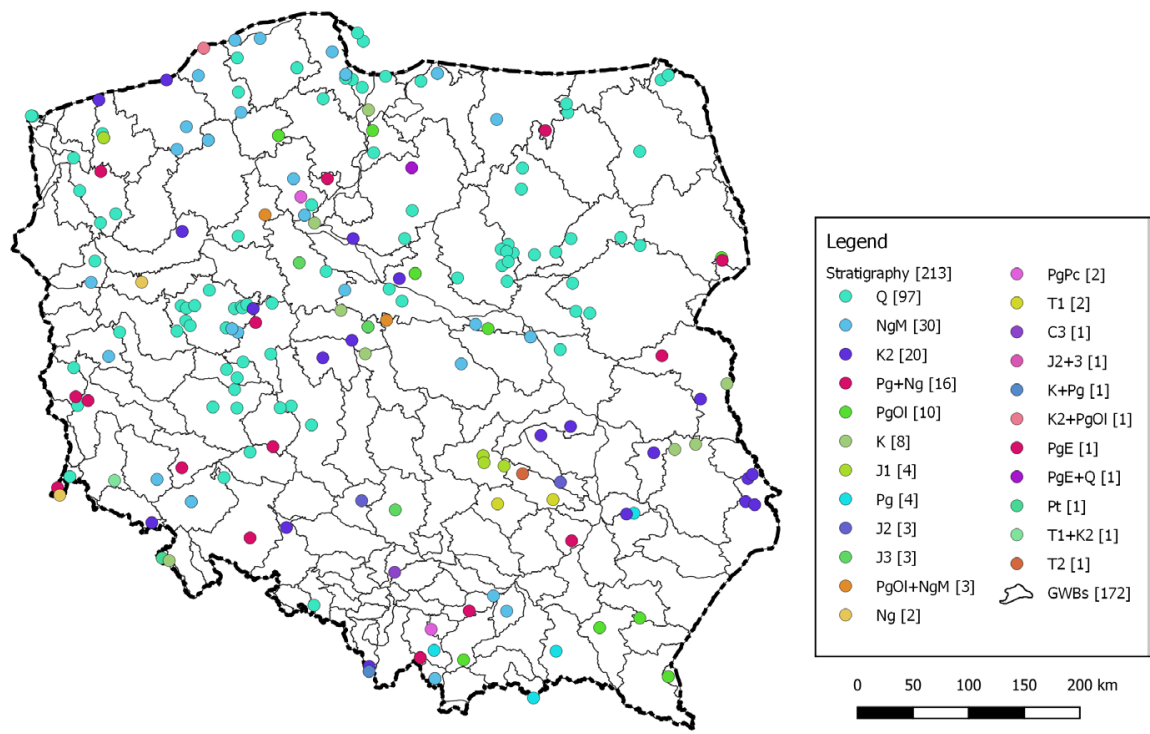

Fig. 7. The distribution of wells of the groundwater observation and research network along with the data on the age of rocks in the aquifer after the first selection stage

Rys. 7. Mapa rozmieszczenia otworów sieci obserwacyjno-badawczej wód podziemnych wraz z informacją o wieku skał ujętej warstwy wodonośnej po wykonaniu pierwszego etapu selekcji 


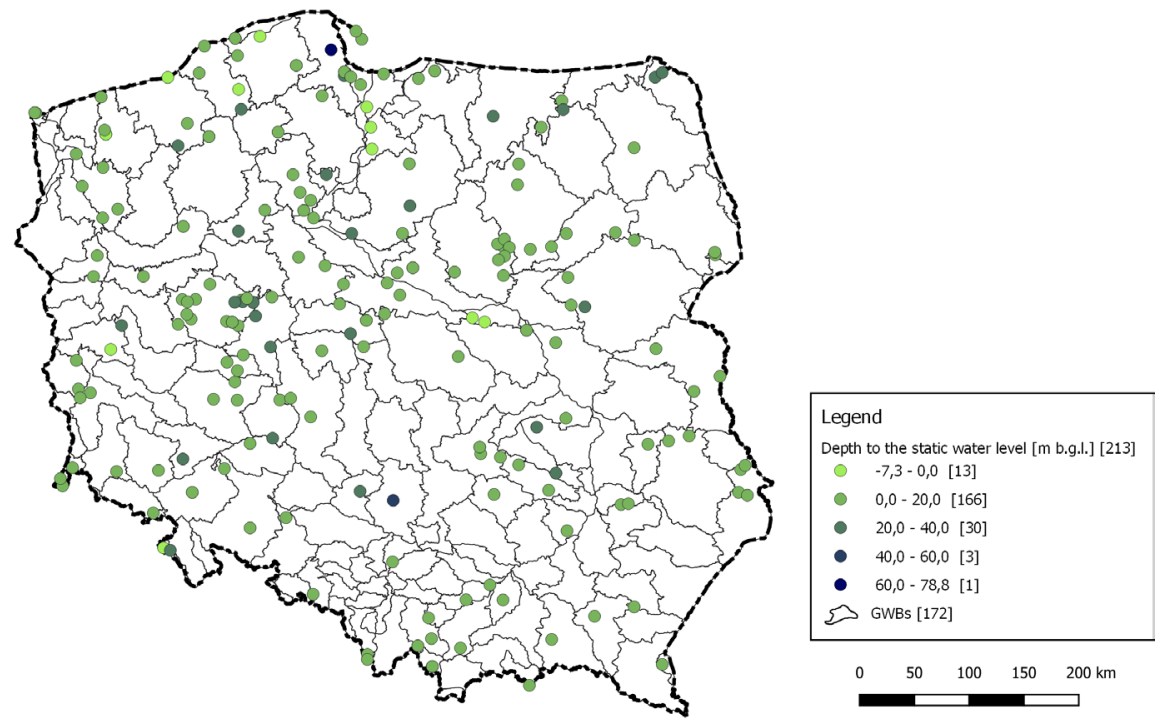

Fig. 8. The distribution of wells of the groundwater observation and research network along with the information on the depth of the static water table after the first selection stage

Rys. 8. Mapa rozmieszczenia otworów sieci obserwacyjno-badawczej wód podziemnych wraz z informacją o głębokości położenia zwierciadła statycznego ujętej warstwy wodonośnej po wykonaniu pierwszego etapu selekcji

\subsection{The second stage of selection}

In the second stage of selection, the lithological development of the aquifers was limited to sands and gravels. As a result, only 142 of the 1324 wells of the groundwater observation and research network ( $10.7 \%$ of the initial pool) were used for further analysis. Almost all wells are located in western and northern Poland (Fig. 9). The selected wells were presented against the map of the Groundwater Bodies (Fig. 10); while water horizons of the GWBs No. 60 (17 wells), No. 11 (6 wells) and No. 49 (5 wells) are worth special attention.

Table 1 shows the extract from the Groundwater Body No. 60 data sheet for the Quaternary lower inter-clay layer. The data sheet confirms the previously accepted criteria for the selection of boreholes and additionally supplements the information on the expected range of the hydraulic conductivity, which is higher than the threshold value (being about $3 \cdot 10^{-5} \mathrm{~m} / \mathrm{s}$ ). 

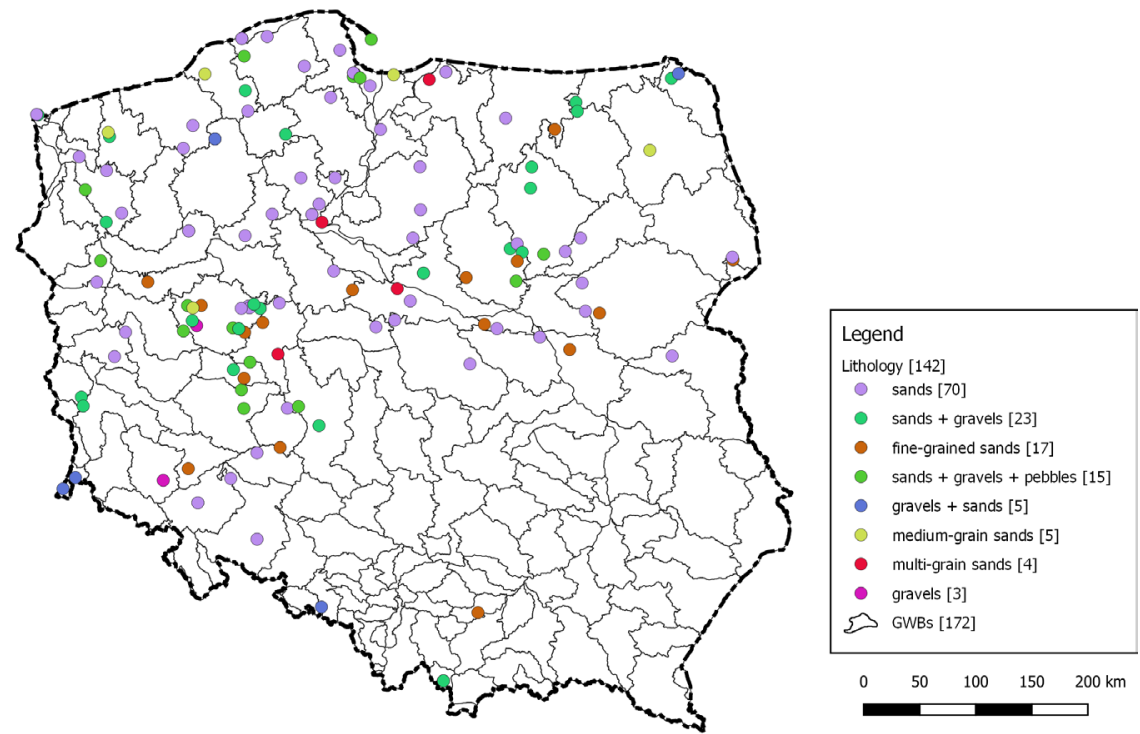

Fig. 9. The distribution of wells of the groundwater observation and research network along with the data on the lithological development of aquifers after the second selection stage

Rys. 9. Mapa rozmieszczenia otworów sieci obserwacyjno-badawczej wód podziemnych wraz z informacją o wykształceniu litologicznym skał budujących ujęty poziom wodonośny po wykonaniu drugiego etapu selekcji

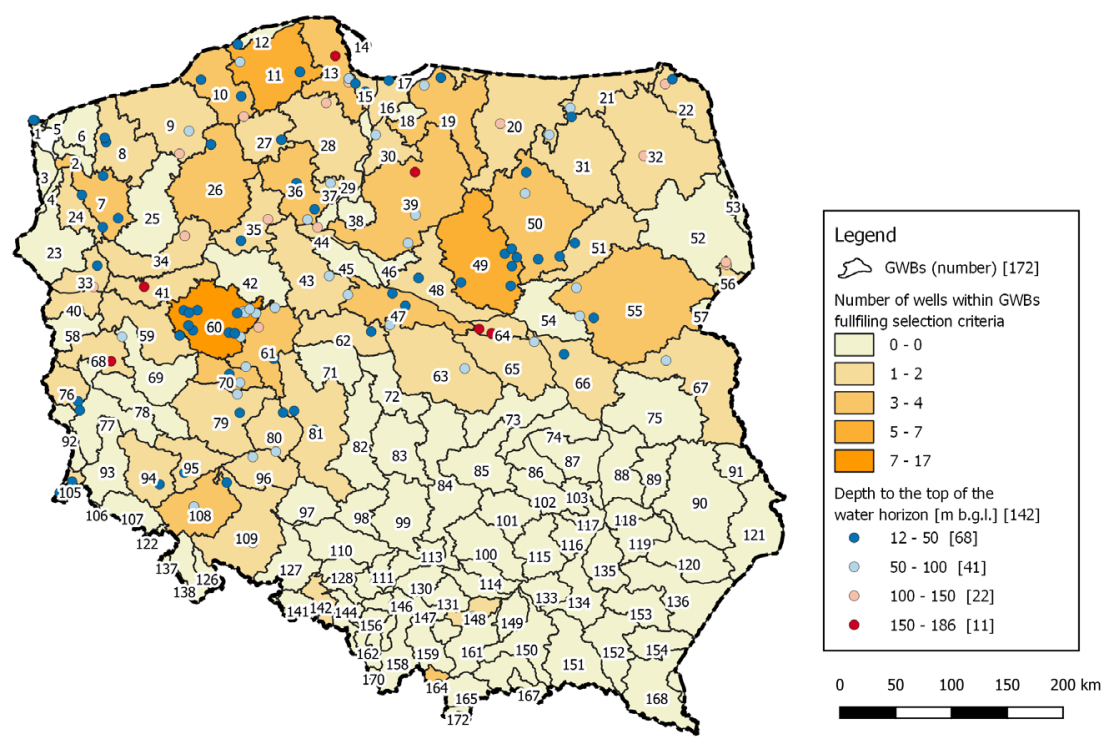

Fig. 10. The number of wells of the groundwater observation and research network against the map of the Groundwater Bodies after the second selection stage

Rys. 10. Mapa liczebności otworów sieci obserwacyjno-badawczej wód podziemnych na tle JCWPd po wykonaniu drugiego etapu selekcji 
TABLE 1. Lower Inter-clay layer of the Groundwater Body No. 60

TABELA 1. Poziom międzyglinowy dolny piętra czwartorzędowego JCWPd nr 60

\begin{tabular}{|c|c|c|c|c|}
\hline \multirow{11}{*}{ 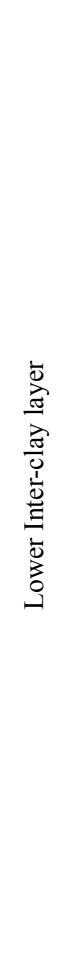 } & Stratigraphy & Lithology & \multicolumn{2}{|c|}{ Aquifer Characteristics } \\
\hline & $\begin{array}{l}\text { Quaternary } \\
\text { (Pleistocene) }\end{array}$ & Sands, gravels & \multicolumn{2}{|c|}{ porous } \\
\hline & Water table type & \multicolumn{3}{|c|}{$\begin{array}{l}\text { Depth of occurrence of aquifers } \\
\text { from-to }[\mathrm{m}]\end{array}$} \\
\hline & confined & \multicolumn{3}{|c|}{$30-100$} \\
\hline & \multicolumn{4}{|c|}{ Hydrogeological parameters of the aquifer } \\
\hline & $\begin{array}{l}\text { Thickness } \\
\text { from - to }\end{array}$ & $\begin{array}{l}\text { Hydraulic conductivity } \\
\text { from-to }\end{array}$ & $\begin{array}{l}\text { Transmissivity } \\
\text { from-to }\end{array}$ & $\begin{array}{l}\text { Storage coefficient } \\
\text { from-to }\end{array}$ \\
\hline & {$[\mathrm{m}]$} & $\begin{array}{l}{[\mathrm{m} / \mathrm{h}]} \\
{[\mathrm{m} / \mathrm{s}]}\end{array}$ & $\begin{array}{l}{\left[\mathrm{m}^{2} / \mathrm{h}\right]} \\
{\left[\mathrm{m}^{2} / \mathrm{s}\right]}\end{array}$ & {$[-]$} \\
\hline & $5-60(10-30)$ & $\begin{array}{c}0.2-3.0 \\
5.5 \cdot 10^{-5}-8.3 \cdot 10^{-4}\end{array}$ & $\begin{array}{c}3-90(10-35) \\
8.3 \cdot 10^{-4}-2.5 \cdot 10^{-2}\end{array}$ & $0.00012-0.0015$ \\
\hline & \multicolumn{4}{|c|}{ Chemical types of groundwater (natural/deviating from natural types) } \\
\hline & \multicolumn{4}{|c|}{$\begin{array}{c}\text { Natural types: } \\
\mathrm{HCO}_{3}-\mathrm{Ca} \text { (bicarbonate-calcium water) } \\
\mathrm{O}_{3}-\mathrm{Ca}-\mathrm{Mg} \text { (bicarbonate-calcium-magnesium water) } \\
\mathrm{CO}_{3}-\mathrm{SO}_{4}-\mathrm{Ca} \text { (bicarbonate-sulphate-calcium water) }\end{array}$} \\
\hline & \multicolumn{4}{|c|}{$\begin{array}{c}\mathrm{HCO}_{3}-\mathrm{Ca}-\mathrm{Na}-\mathrm{Mg} \text { (bicarbonate-calcium-sodium-magnesium water) } \\
\mathrm{HCO}_{3}-\mathrm{Cl}-\mathrm{Ca}-\mathrm{Na}-\mathrm{Mg} \text { (bicarbonate-chloride-calcium-magnesium-sodium water) } \\
\mathrm{HCO}_{3}-\mathrm{Ca}-\mathrm{Na} \text { (bicarbonate-calcium-sodium water) } \\
\mathrm{HCO}_{3}-\mathrm{Ca}-\mathrm{Mg}-\mathrm{Na} \text { (bicarbonate-calcium-magnesium-sodium water) }\end{array}$} \\
\hline
\end{tabular}

Source: characteristic sheet of the Groundwater Body no. 60 (PGI-NRI, PHS 2019).

\subsection{Third stage of selection}

Considering the fact that ATES systems are most often used in commercial facilities, public utility buildings, and residential buildings, the criterion was assumed that the ATES system must be located in an area where the population density is at least two times higher than the average population density in Poland, i.e. around 250 persons $/ \mathrm{km}^{2}$. A vector map with precisely applied demographic information (grid node distance of $1 \mathrm{~km}$ ) was downloaded from the Geostatistics Portal (CSO 2019).

As a result of the third stage of selection, 29 wells meeting all previous criteria were determined (Fig. 11). These wells are located, among others, in the following cities: Warsaw, Gdańsk, Wrocław, Bydgoszcz, Słupsk, Stargard, Racibórz, Szczytno, and Mrągowo. 


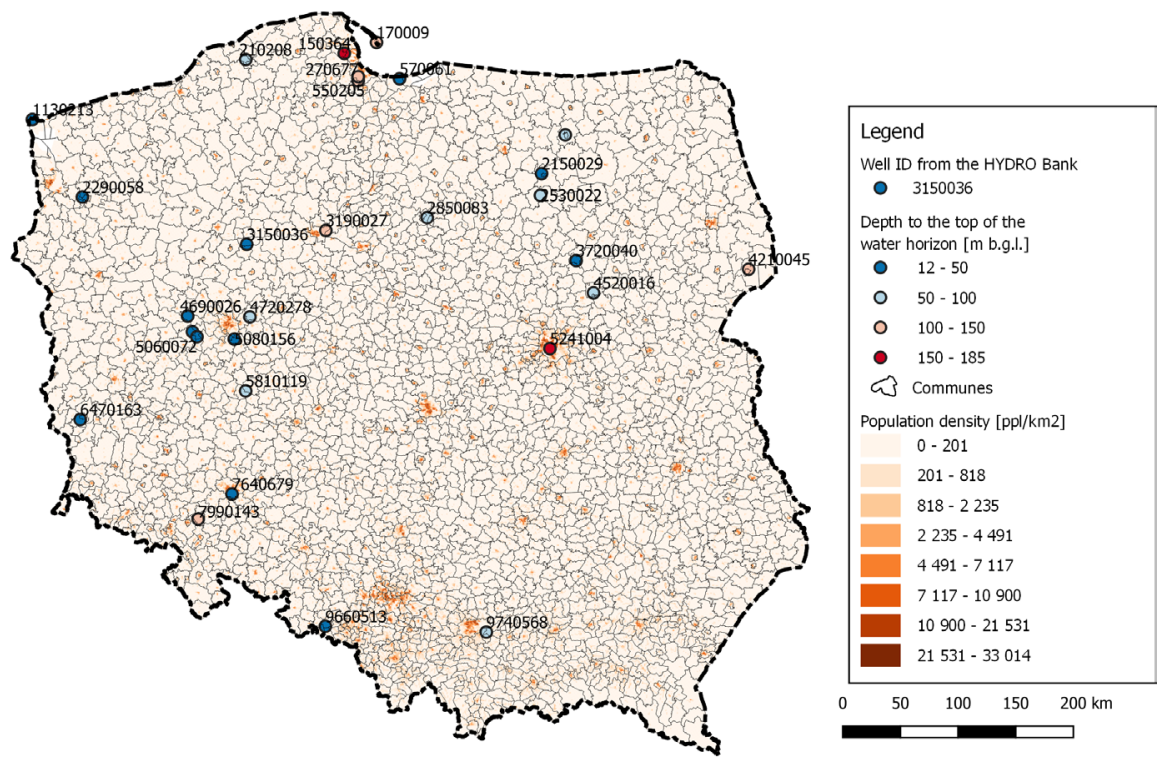

Fig. 11. The distribution of wells of the groundwater observation and research network against the population density of Poland (CSO 2019) after the third stage of selection

Rys. 11. Mapa rozmieszczenia otworów sieci obserwacyjno-badawczej wód podziemnych na tle mapy gęstości zaludnienia Polski po wykonaniu trzeciego etapu selekcji

\section{Conclusions}

The aim of this work was to initiate analytical studies on the possibility of heat storage in shallow aquifers (ATES) in Poland. The purpose of this technology, particularly popular in the Netherlands ( $90 \%$ of all systems in the world), is to provide heat and cold for low-temperature consumers, i.e. those whose supply temperature typically does not exceed $50^{\circ} \mathrm{C}$, and at the same time they require cooling during the summer season. The world experience, mainly from Benelux and Scandinavia, indicates that low-temperature heat storage in shallow aquifers is a proven technology that does not pose significant technical difficulties, provided there is regular monitoring of groundwater quality, early detection and prevention of colmatation of wells, and the ongoing maintenance of the system. A well-designed ATES system is characterized by a very short payback time - even below 5 years with a heating/cooling demand of several MW.

At this stage of the research, the authors used publicly available data of the groundwater observation and research network and the Groundwater Bodies data sheets (GWBs). As a result of the three-stage selection carried out based on the requirements set for ATES systems, preliminary 
locations for the first installations for heat and cold storage in shallow aquifers were pre-determined. The analysis shows that aquifers with the desired reservoir parameters are located primarily in northern and western Poland, including the main cities: Warsaw, Gdańsk, Wrocław, or Bydgoszcz. The mentioned areas require a much deeper hydrogeological analysis before taking further steps, in particular: verification of the capacity of the wells, the hydraulic conductivity and natural groundwater flow velocity within the aquifer, as well as the analysis of the chemical composition of the waters. Performing computer simulations showing the long-term exploitation of the aquifer under heat storage conditions is advisable only after positive verification of reservoir parameters of the aquifer.

The analysis of the literature on the experience of countries leading in the implementation of ATES indicates that the main obstacles in the initial stages of development are the lack of awareness about the technology itself, the lack of interest from central and local authorities, the lack of (or unclear) legal regulations regarding obtaining permits for the development of groundwater heat storage facilities, and technical failures during the implementation of pilot installations. The development of a comprehensive study on the applicability of ATES system in Poland and maps in the GIS environment (available publicly via the Internet) could be an impulse for the development of this technology in Poland.

\section{References}

Bloemendal et al. 2015 - Bloemendal, M., Olsthoorn, T. and VAN DEN Ven F. 2015. Combining climatic and geo-hydrological preconditions as a method to determine world potential for aquifer thermal energy storage. Science of the Total Environment 538, pp. 621-633, DOI: 10.1016/j.scitotenv.2015.07.084.

Bloemendal et al. 2018 - Bloemendal, M., JaXA-Rosen, M. and Olsthoorn, T. 2018. Methods for planning ATES systems. Applied Energy 216, pp. 534-557, DOI: 10.1016/j.apenergy.2018.02.068.

BUJAKOWSKI et al. 2016 - BuJAKOWSKI, W., BIELEC, B. and SKRZYPCZAK, R. 2016. ATES technology and the possibility of its application in the Piotrków region (Technologia ATES i możliwości jej zastosowania $w$ rejonie piotrkowkim). Zeszyty Naukowe Instytutu Gospodarki Surowcami Mineralnymi i Energia Polskiej Akademii Nauk 92, pp. 373-390 (in Polish).

CHDB (Central Hydrogeological Data Bank) 2019. The HYDRO BANK [Online] https://www.pgi.gov.pl/ en/phs/data/8880-the-hydro-bank.html [Accessed: 2019-01-16].

CSO (Central Statistical Office) 2019. Geostatistics Portal. [Online] https://geo.stat.gov.pl/start/-/asset_publisher/jNfJilujcyRp/content/id/36734 [Accessed: 2019-01-22].

EC (European Commission) 2017. EU Energy in figures - statistical pocketbook 2017. Luxembourg: Publications Office of the European Union.

EC (European Commission) 2018. Energy, transport and environmental indicators, 2018 edition. Eurostat Statistical Books. Luxembourg: Publications Office of the European Union.

ETP RHC (European Technology Platform on Renewable Heating and Cooling) 2013. Strategic Research and Innovation Agenda for Renewable Heating \& Cooling. Brussels: Renewable Energy House.

Eurostat 2018. Energy consumption in households. [Online] https://ec.europa.eu/eurostat/statistics-explained/index.php?title=Energy_consumption_in_households [Accessed: 2019-01-24]. 
Fleuchaus et al. 2018 - Fleuchaus, P., Godschalk, B., Stober, I. and Blum, P. 2018. Worldwide application of aquifer thermal energy storage - A review. Renewable and Sustainable Energy Reviews 94, pp. 861876. DOI: 10.1016/j.rser.2018.06.057.

Herbich et al. 2005 - Herbich, P., Hordejuk, T., KAZIMIERSKi, B., Nowicki, Z., SAdurski, A. and SKRZYPCZYK, L. 2005. Groundwater Bodies in Poland (Jednolite części wód podziemnych (hydrogeosomy) w Polsce). [In:] Sadurski, A. and Krawiec, A. (eds) Proceedings of XII Conference on Contemporary Problems of Hydrogeology (Wspótczesne Problemy Hydrogeologii). Toruń: Publishing House of M. Kopernik University, pp. 269-274 (in Polish).

Honest Buildings. Cofely Energy Solutions: Overhoeks. [Online] https://www.honestbuildings.com/project/\#!/view/73857/overhoeks [Accessed: 2019-01-23]

IPCC (Intergovernmental Panel on Climate Change) 2014 - Climate Change 2014. Impacts, adaptation, and vulnerability. Part A: Global and sectoral aspects. Working Group II Contribution to the Fifth Assessment Report of the Intergovernmental Panel on Climate Change, Chapter 10: Key Economic Sectors and Services, 659-708. Cambridge University Press.

KAZMANN, R.G. 1971. Exotic use of aquifers. Journal of the Irrigation and Drainage Division 97(3), pp. $515-522$.

KWESTARZ, M. 2016. Heat storage - types of storages (Magazynowanie ciepla - rodzaje magazynów) Czysta Energia 12, pp. 29-35 (in Polish).

LEE, K.S. 2013. Underground Thermal Energy Storage. Green Energy and Technology. London: Springer-Verlag.

LEMOINE, G. 2016. Methodological approach analysis of low-temperature energy potential for late-glacial areas on the example of the Kashubian Lake District (Analiza niskotemperaturowego potencjatu energetycznego obszarów młodoglacjalnych na przykładzie Pojezierza Kaszubskiego - Podejście metodologiczne). Technika Poszukiwań Geologicznych. Geotermia, Zrównoważony Rozwój 55(1), pp. 151-171 (in Polish).

LEMOINE, G. 2018. Seasonal thermal energy storage perspectives in a shallow aquifer of young glacialareas on the example of Słuszewska ice-marginal valley in the Żarnowiec morainic plateau (Perspektywy międzysezonowego magazynowania ciepła $w$ ptytkich warstwach wodonośnych z obszarów młodoglacjalnych na przykładzie Rynny Sluszewskiej Wysoczyzny Żarnowieckiej). Technika Poszukiwań Geologicznych. Geotermia, Zrównoważony Rozwój 57(2), pp. 55-77 (in Polish).

MalinA, G. and BuJAK, I. 2017. Evaluation of a Potential to Combine Aquifer Thermal Energy Storage with Groundwater Remediation (Ocena możliwości skojarzenia magazynowania energii cieplnej $w$ warstwie wodonośnej z remediacją wód podziemnych). Ochrona Środowiska - Environmental Pollution Control 39(3), pp. 9-18 (in Polish).

MEYER, C.F. and TodD, D.K. 1973. Conserving energy with heat storage wells. Environmental Science \& Technology 7(6), pp. 512-516. DOI: 10.1021/es60078a009.

MIECZNIK, M. 2016. Underground thermal energy storage - methods and applications (Podziemne magazynowanie energii cieplnej - metody i zastosowania). Przeglad Geologiczny 64(7), pp. 464-471 (in Polish).

NiELSEN, K. 2003. Thermal Energy Storage. A State-of-the-Art. Trondheim: Norwegian University of Science and Technology.

Nordell et al. 2015 - Nordell, B., SniJders, A. and Stiles, L. 2015. The use of aquifers as thermal energy storage (TES) systems. [In:] Cabeza L.F. (Ed.) Advances in Thermal Energy Storage Systems. Woodhead Publishing, pp. 87-115.

PGI-NRI (Polish Geological Institute - National Research Institute, The Polish Hydrogeological Survey) 2017. Report on the condition of groundwater bodies in river basins - as of 2016. Volume 2 - tabular attachments (Raport o stanie jednolitych części wód podziemnych $w$ dorzeczach - stan na rok 2016. Tom 2 - załaczniki tabelaryczne). Warsaw: Chief Inspectorate Of Environmental Protection (in Polish). 
PGI-NRI (Polish Geological Institute - National Research Institute, The Polish Hydrogeological Survey) 2019. Groundwater Bodies (Jednolite Części Wód Podziemnych) [Online] https://www.pgi.gov.pl/psh/ zadania-psh/8913-zadania-psh-jcwpd.html [Accessed: 2019-01-21] (in Polish).

Sauty et al. 1982a - SaUty, J.P., Gringarten, A.C., Menjoz, A. and Landel, P.A. 1982a. Sensible energy storage in aquifers: 1 . Theoretical study. Water Resources Research 18(2), pp. 245-252. DOI: 10.1029/WR018i002p00245.

SAUTY et al. 1982b - SAUTY, J.P., Gringarten, A.C., FABris, H., Thiery, D., Menjoz, A. and LANDEL, P.A. 1982b. Sensible energy storage in aquifers: 2. Field Experiments and comparison with theoretical results. Water Resources Research 18(2), pp. 253-265. DOI: 10.1029/WR018i002p00253.

Schaetzle et al. 1980 - Schaetzle, W. J., Brett, C.E., GrubBs, D.M. and Seppanen, M.S. 1980. Thermal energy storage in aquifers: Design and applications. New York: Pergamon.

SKRZYPCZAK et al. 2017 - SKRZYPCZAK, R., KASZTELEWICZ, A., LANKOF, L. and MIECZNIK, M. 2017. Analysis of geological conditions for aquifer thermal energy storage (ATES) in Sochaczew (Analiza warunków geologicznych dla systemu podziemnego magazynowania ciepla (ATES) w mieście Sochaczew). Technika Poszukiwań Geologicznych. Geotermia, Zrównoważony Rozwój 56(2), pp. 69-83 (in Polish).

SOMMER, W.T. 2015. Modelling and monitoring of aquifer thermal energy storage. Impacts of heterogeneity, thermal interface and bioremediation. PhD Thesis, Wageningen: Wageningen University.

Underground Energy LLC 2019. ATES - Aquifer Thermal Energy Storage. How efficient is ATES? [Online] http://underground-energy.com/our-technology/ates/ [Accessed: 2019-01-24].

Vanhoudt et al. 2011 - Vanhoudt, D., Desmedt, J., Van Bael, J., Robeyn, N. and Hoes, H. 2011. An aquifer thermal energy storage in Belgian hospital: Long-term experimental evaluation of energy and cost savings. Energy and Buildings 43(12), pp. 3657-3665. DOI: 10.1016/j.enbuild.2011.09.040.

WERNER, D. and KLEY, W. 1977. Problems of heat storage in aquifers. Journal of Hydrology 34(1-2), pp. 35-43. DOI: 10.1016/0022-1694(77)90061-0.

Zeiler et al. 2016 - ZeILER, W., GVOZDENOVI, K., DE BONT, K. and MAASSEN, W. 2016. Toward cost-effective nearly zero energy buildings: the Dutch situation. Science and Technology for the Built Environment 22(7), pp. 911-927. DOI: 10.1080/23744731.2016.1187552.

\section{Wstępna ocena możliwości wykorzystania technologii ATES w Polsce przez odbiorców niskotemperaturowego ciepła i chłodu}

\section{Streszczenie}

Celem artykułu jest wstępna ocena możliwości wykorzystania w Polsce technologii sezonowego magazynowania ciepła i chłodu w płytkich warstwach wodonośnych (ATES - Aquifer Thermal Energy Storage). Zasadniczym przeznaczeniem technologii ATES jest dostarczanie niskotemperaturowego ciepła i chłodu 
do odbiorców wielkopowierzchniowych, którzy w ciągu roku wykazują zapotrzebowanie na obie formy ciepła. Badania naukowców z Delft University w Holandii wskazują na bardzo korzystne warunki hydrogeologiczne i klimatyczne na większości obszaru Polski do jej pomyślnego rozwoju. Aby to wstępnie potwierdzić, autorzy wykorzystali ogólnodostępne dane hydrogeologiczne, w tym informacje złożową pozyskaną z 1324 otworów sieci obserwacyjno-badawczej wód podziemnych (SO-BWP) oraz 172 kart informacyjnych jednolitych części wód podziemnych (JCWPd). Korzystając z dobrze opisanych w literaturze światowej wymagań stawianych systemom ATES, przeprowadzono w środowisku GIS selekcję otworów, które ujmują poziomy wodonośne spełniające wymagane kryteria. Wstępna ocena wskazuje na możliwość pomyślnego wdrożenia technologii ATES w Polsce, w szczególności w północnej i zachodniej części kraju, w tym na obszarze takich miast jak Gdańsk, Warszawa, Wrocław, Bydgoszcz, Słupsk i Stargard.

SŁowA KLUCZOWE: Aquifer Thermal Energy Storage, ATES, magazynowanie ciepła w warstwach wodonośnych, podziemne magazynowanie ciepła i chłodu 
